partnership is to perceive citizens and their associations as equal partners in the decision-making process. The law should specify the degree of responsibility of the official person for non-compliance with the adopted decisions.

Key words: e-governance, principles of e-governance.

DOI: $10.36695 / 2219-5521.4 .2019 .20$

УДК 342.9

\title{
В.А. МИКОЛАєЦЬ
}

\author{
Вікторія Анатоліївна Миколаєць, кандидат \\ юридичних наук, докторант МАУП*
}

ORCID: 0000-0002-9731-3884

\section{ЗРАЗКОВІ ТА ТИПОВІ СПРАВИ В АДМІНІСТРАТИВНОМУ СУДОЧИНСТВІ ЛИТВИ}

Постановка проблеми. Згідно зі ст. 55 Конституції України ${ }^{1}$ кожному гарантується право на оскарження в суді рішень, дій чи бездіяльності органів державної влади, органів місцевого самоврядування, посадових і службових осіб. Тобто гарантування захисту прав громадян у відносинах з адміністративними органами є обов’язком держави, який став однією із першопричин створення в Україні адміністративної юстиції, яка, з одного боку, захищає права громадян, а, з іншого, забезпечує законність діяльності органів державної влади. Із самого початку створення адміністративної юстиції в наший державі вітчизняний законодавець опирався на досвід іноземних держав, передусім європейських. Йдеться не про механічне перенесення окремих елементів зарубіжних моделей, а про реформування національного законодавства згідно 3 чинними соціально-політичними умовами, досвідом більш розвинених держав, а також із урахуванням національних правових традицій. Тож теоретичні та прикладні розробки щодо запровадження в Україні адміністративної юстиції європейського зразку не втрачають своєї актуальності, а тому дослідження будь-яких правових інститутів доречно здійснювати крізь призму досвіду тих держав, які успішно їх впровадили в свої правові системи.

В основу механізму зразкових та типових справ в адміністративному судочинстві ліг інститут пілотних рішень, які виносить Європейський суд з прав людини. 3 часу прийняття першого пілотного рішення застосування даного інструменту було спрямовано насамперед на зменшення навантаження на суди та суддів. За своєю сутністю пілотні рішення Свропейського суду з прав людини являють собою вказівки державним органам на існування системної проблеми, яка стосується великої кількості осіб, та рекомендації щодо усунення виявлених порушень. Шляхом впровадження інституту пілотних рішень було розв'язано одразу два завдання: по-перше, впроваджено інститут, спрямований на вирішення багаторазово повторюваних проблем; по-друге, даний механізм сприяв вирішенню справ, що випливають зі стійкого системного неправильного функціонування адміністративних і правозастосовних органів правової системи держави. Як зазначається в науковій літературі, така процедура була впроваджена у багатьох судових системах Свропи: в Угорщині, Португалії, Франції, Італії, Австрії, Словенії, Литві. Водночас існує практика, коли європейські країни відмовились від впровадження таких процедур. Наприклад, законодавці Латвії аргументували свою незгоду 3 даним нововведенням можливими запереченнями учасників процесу проти визначення справи як типової для постанови зразкового рішення; тим, що фактичні обставини у справі можуть різною мірою відрізнятися, а суд може їх врахувати як ідентичні; а також тим, що у зв'язку із запровадженням цього інституту зросте навантаження на Верховний Суд². Україна у даному контексті стала на сторону держав, у яких функціонують механізми зразкових та типових справ в адміністративному судочинстві, і при цьому відсутня певна єдина модель, досвід якої було запозичено Україною. Український варіант зразкових та типових справ в адміністративному судочинстві не був повністю скопійований із певної конкретної моделі й має свої особливості.

Аналіз останніх досліджень та публікацій. Серед дослідників зарубіжних моделей механізму зразкових та типових справ в адміністративному судочинстві відзначимо внесок таких, як: С.В. Боднар, М.А. Бояринцева, А.В. Журавльов, В.В. Ільков, І.А. Качур, І.В. Мирончук, Л.І. Пахолок, В.Б. Пчелін, А.О. Селіванов, Т.Г. Стрілець, А.О. Черникова, В.І. Шишкін. Але водночас варто враховувати те, що праці перелічених авторів були присвячені більш загальним питанням адміністративного судочинства, які у тому числі стосувалися й інститутів зразкових та типових справ. Також із даного приводу варто зазначити, що впровадження даних механізмів у Кодексі адміністративного судочинства України ${ }^{3}$ не применшило актуальності наукових досліджень зарубіжних моделей, а навпаки, надало таким дослідженням важливого значення. Зарубіжний досвід функціонування механізмів зразкових та типових справ в адміністративному судочинстві має вивчатись $\mathrm{i}$ надалі з метою вдосконалення чинного законодавства, практики його застосування, продовження процесу приведення існуючої правової системи до міжнародних стандартів.

(C) В.А. Миколаєць, 2019

* Victoria Mykolayets, Ph.D. in Law, Doctoral candidate of the Interregional Academy of Personnel Management 
Формулювання мети статті. Метою статті є встановлення специфіки зразкових та типових справ у адміністративному судочинстві Литви.

Виклад основного матеріалу дослідження. Окрім провідних держав Європейського Союзу вважаємо, що Україні варто опиратись на досвід держав, близьких історично, соціально-політично, територіально. Україна та ряд європейських держав розбудовували власні правові системи із ідентичних витоків, тому такий досвід буде легше запровадити у вітчизняну систему адміністративного судочинства.

Однією із держав, досвід якої варто дослідити першочергово, є Литва. Актуальність звернення до аналізу законодавства даної держави зумовлена низкою причин, як пов'язаних безпосередньо із механізмами зразкових та типових справ в адміністративному судочинстві, так і причинами, не пов'язаними із цим. Поперше, варто враховувати те, що Литва підписала угоду про асоціацію із Свропейським Союзом ще в червні 1995 р.4, а вже в 1998 р. подала заявку про вступ до Європейського Союзу5. Тобто, по суті, Литва реалізувала нині задекларовані Україною цілі більш ніж на півтора десятки років раніше, аніж Українаб: обидві держави після здобуття незалежності вони стикнулись зі схожими політичними, економічними та соціальними проблемами, обидві держави на початку 90-х років минулого століття розпочали будівництво незалежних держав iз проголошення курсу на вступ до Європейського Союзу. I при цьому на сучасному етапі Литва являє собою успішну європейську державу та є важливим стратегічним партнером України. По-друге, Литва є державою, яку варто віднести до групи держав континентальної моделі забезпечення єдності судової практики. У цій державі функціонує Вищий адміністративний суд Литви, а Законом Литви «Про провадження в адміністративних справах» від 14 січня 1999 р. № VIII-10297 регламентовано інститути зразкових та типових справ. Потретє, на відміну від свого сусіда, Латвії, Литва не відмовилась від механізмів зразкових та типових справ в адміністративному судочинстві, які успішно функціонують і дотепер. Сам тому дослідження досвіду функціонування механізмів зразкових та типових справ в адміністративному судочинстві Литви у контексті європейської інтеграції є одним із першочергових.

Питання зразкових та типових справ в адміністративному судочинстві в Литві урегульовується нормами Закону Литви «Про провадження в адміністративних справах» від 14 січня 1999 р. № VIII-1029, у якому цим механізмам присвячено Главу 4 Розділу II «Модельний судовий процес». На нашу думку, термін «модельний» відповідає вітчизняному аналогу «зразковий». Одним із значень терміна «модельний», згідно 3 Великим тлумачним словником сучасної української мови, є «зразковий, взірцевий примірник» 8 . Тобто модельна адміністративна справа в адміністративному судочинстві Литви є тотожним поняттям до зразкової адміністративної справ в адміністративному судочинстві України. Щодо типових справ, то в законодавстві Литви вони визначаються як «однорідні». Наприклад, у ст. 127 Закону Литви «Про провадження в адміністративних справах» від 14 січня 1999 р. № VIII-1029 йдеться про індивідуальні однорідні справи. «Однорідний», згідно із Великим тлумачним словником сучасної української мови, означає «який характеризується однаковими рисами, ознаками» ${ }^{9}$. Схожим чином можна пояснити і термін «типовий» - «який визначається ознаками, властивими якій-небудь сукупності осіб, явищ, предметів і т.д.» ${ }^{10}$. А отже, між індивідуальними однорідними справами в адміністративному судочинстві Литви та типовими адміністративними справами в адміністративному судочинстві України також можна провести чіткі зв'язки та взаємозалежності.

Зміст ст. 127 Закону Литви «Про провадження в адміністративних справах» від 14 січня 1999 р. № VIII-1029 є схожим до змісту ст. 290 Кодексу адміністративного судочинства України ${ }^{11}$. Так само визначається, що якщо в провадженні одного чи різних адміністративних судів перебуває декілька індивідуальних однорідних справах, одна або декілька із них можуть бути розглянуті у порядку модельної адміністративної справи. При цьому, на відміну від законодавства України, законодавство Литви передбачає мінімальну кількість індивідуальних однорідних справ, необхідних для провадження у модельній адміністративній справі. Доцільно зауважити, що в ч. 1 ст. 290 Кодексу адміністративного судочинства України вітчизняний законодавець вжив розмите формулювання «кількість яких визначає доцільність ухвалення зразкового рішення». У свою чергу, законопроект № 623212 передбачав мінімальну кількість - 10 типових справ. Литовське законодавство (ч. 2 ст. 127) у даному контексті передбачає, що у разі, якщо в одному або декількох окружних адміністративних судах розглядаються понад 20 індивідуальних однорідних справ, одна або більше із зазначених справ можуть розглядатися в спеціальному порядку і називатися модельним справою (модельними справами). Тож даний досвід, на нашу думку, міг би бути взятий до уваги вітчизняним законодавцем, адже в цій роботі ми вже вказували на те, що невизначеність у кількості типових справ, наявність яких зумовлює потребу в ухваленні зразкового рішення, є однією із основних практичних проблем правового регулювання механізмів зразкових та типових справ в адміністративному судочинстві.

Аналізуючи зміст ст. 128 Закону Литви «Про провадження в адміністративних справах» від 14 січня 1999 р. № VIII-102913, звернемо увагу на те, що ініціювати відкриття провадження у модельній справі може голова окружного адміністративного суду за клопотанням судді (колегії суддів) шляхом винесення ухвали. Так само голову окружного адміністративного суду наділено компетенцією об'єднувати кілька індивідуальних однорідних або модельних справ в одну модельну справу. Голова Вищого адміністративного суду Литви вступає у дану процедуру лише у тому випадку, коли декілька індивідуальних однорідних або модельних справ знаходяться в різних окружних адміністративних судах. У такому випадку Голова своїм рішенням здійснює їх об'єднання в одну модельну справу, а також утворює колегію суддів для розгляду даної справи. Для порівняння, згідно із ч. 3 ст. 290 Кодексу адміністративного судочинства України 14 , вирішення питання про відкриття провадження у зразковій справі, відмова у відкритті провадження у зразковій справі та розгляд 
зразкової справи здійснюється колегією суддів Верховного Суду у складі не менше п’яти суддів. Тобто питання відкриття провадження у зразковій справі повністю перебуває в компетенції Верховного Суду нашої держави. У даному контексті зробимо висновок, що все ж в Україні даний механізм є більш досконалим. Надання головам місцевих адміністративних судів повноважень ініціювати відкриття провадження у зразковій справі значно ускладнило б практичне застосування зразкових рішень. Це може призвести до неоднорідності зразкової практики, прийняття різних рішень у типових справах. На нашу думку, більш доцільно повністю передати дану компетенцію у відання Верховного Суду - так, як це і було зроблено в Україні. Це $\epsilon$ гарантією однозначності у зразкових справах та додатковою гарантією того, що в типових справах, які характеризуються ідентичними ознаками, не будуть прийняті різні рішення.

Так само як і в Україні, в Литві учасники модельного процесу інформуються про відкриття провадження у такій справі шляхом публікації повідомлення про це на офіційному веб-ресурсі Вищого адміністративного суду Литви 7 . У контексті України дане положення відзначалось нами як доречне. Втім, вказувалось на те, що в сучасних умовах воно може призвести до певних ускладнень в інформуванні, із огляду на порівняно низький відсоток користувачів всесвітньої мережі «Інтернет» серед населення нашої держави. Для порівняння, станом на липень 2019 р. користувачами Інтернету були близько 90,9 \% населення Литви ${ }^{15}$. Отже, дане положення є значно ефективнішим для Литви. У контексті України нами зроблено висновок, що все ж на даному етапі більш доречно передбачити альтернативні способи повідомлення учасників зразкової справи.

Аналізуючи положення ч. 4 ст. 128 Закону Литви «Про провадження в адміністративних справах» від 14 січня 1999 р. № VIII-102916, зазначимо, що провадження у типовій справі так само, як і в Україні, призупиняється у зв'язку із відкриттям провадження у зразковій справі. Проте, якщо в Україні може бути оскаржене лише рішення у типовій чи зразковій справі, то в Литві сторонам типових справ також надано право оскаржувати ухвалу суду про призупинення розгляду однорідної (типової) справи для розгляду модельної (зразкової) справи на тій підставі, що справа, яка розглядається, не відповідає критеріям типовості. На нашу думку, таке положення було б доречно запозичити у вітчизняне законодавство, оскільки на даному етапі учасники адміністративних спорів позбавлені можливості впливати на провадження в зразкових спорах, не зважаючи на те, що вони безпосередньо стосуються їхніх прав. Варто враховувати те, що розгляд справи Верховним Судом як зразкової, може негативно вплинути на забезпечення прав сторін - наприклад, це може суттєво затягнути розгляд справи, або ж рішення буде прийняте, опираючись на висновки Верховного Суду, а не на реальні обставини справи. Тому, на наше переконання, варто надати можливість сторонам типової справи оскаржувати ухвалу про відкриття провадження у зразковій справі.

Згідно із ч. 1 ст. 129 Закону Литви «Про провадження в адміністративних справах» від 14 січня 1999 р. № VIII-1029, модельна справа розглядається колегією окружного адміністративного суду в складі трьох суддів, а розгляд модельних справ у Вищому адміністративному суді Литви здійснюється розширеною колегією суддів або пленарною сесією суду. Для порівняння, в Україні розгляд зразкової справи здійснюється колегією суддів Верховного Суду у складі не менше п'яти суддів ${ }^{17}$. Частиною 3 цієї статті передбачено можливість залучення заінтересованої особи до розгляду зразкової справи у разі подання такої заяви та встановлення судом того, що участь такої особи є обов'язковою для належного розгляду модельної справи. Звернемо увагу на те, що в Україні відсутній механізм ініціювання власної участі в зразковій справі.

Аналізуючи процедуру провадження у індивідуальних однорідних справах у Литві, регламентованій у ст. ст. 130 та 131 Закону Литви «Про провадження в адміністративних справах» від 14 січня 1999 р. № VIII-1029, доходимо висновку, що вона є ідентичною до провадження в типових справах в Україні. Так само, розгляд однорідної справи призупиняється до винесення модельного рішення, так само, після набрання законної сили рішенням суду в модельній справі, провадження в індивідуальній справі поновляється. Рішення в модельній справі публікується на веб-ресурсі Вищого адміністративного суду Литви, і про нього повідомляються усі місцеві адміністративні суди. Після набрання законної сили рішення у модельній справі індивідуальні однорідні спори можуть розглядатись в спрощеному порядку - одним суддею, у порядку письмового провадження. На нашу думку, даний досвід було б доцільно запровадити і в Україні, оскільки це відповідає тим цілям, для досягнення яких, власне, i було запроваджено механізми зразкових та типових справ в адміністративному судочинстві - це сприятиме спрощенню проваджень у типових справах та розвантаженню судів. У ч. 4 ст. 131 Закону Литви «Про провадження в адміністративних справах» від 14 січня 1999 р. № VIII-102918 здійснено уточнення, що такий скорочений розгляд можливий лише у тому випадку, якщо законність і обгрунтованість рішення суду першої інстанції в модельній справі була перевірена в апеляційному порядку у Вищому адміністративному суді Литви або якщо Вищий адміністративний суд Литви ухвалив рішення в модельній справі. Встановлення даного положення зумовлене тим, що рішення в модельних справах у Литві, як зазначалось нами, можуть прийматись місцевими адміністративними судами. В Україні такою компетенцією наділений лише Верховний Суд, а отже, регламентація такої додаткової гарантії не потрібна.

Загалом, підсумовуючи дослідження досвіду Литви щодо правового регулювання зразкових та типових справ в адміністративному судочинстві, ми дійшли висновку про існування низки свідчень того, що при розробці механізмів зразкових та типових справ український законодавець міг звернутись до досвіду даної держави. Зміст § 3 Глави 11 Розділу II «Позовне провадження» Кодексу адміністративного судочинства України та Глави 4 Розділу II «Модельний судовий процес» Закону Литви «Про провадження в адміністративних справах» від 14 січня 1999 р. № VIII-102919 у багатьох моментах є ідентичним. У процесі аналізу нами виді- 
лено такі особливості правового регулювання зразкових та типових справ в адміністративному судочинстві Литви, які відрізняють його від української моделі правового регулювання цих інститутів:

1) зразкові й типові справи дістали назву «модельних» та «індивідуальних однорідних», проте їх сутність є ідентичною;

2) зразкові справи можуть розглядатись місцевими адміністративними судами;

3) для відкриття провадження у зразковій справі необхідне перебування у провадженні одного або декількох адміністративних судів щонайменше 20 типових адміністративних справ;

4) ухвала щодо відкриття провадження у зразковій справі може бути оскаржена учасниками типової справи;

5) після набрання законної сили рішенням у зразковій справі типові справи можуть розглядатись у спрощеному порядку.

Висновки. Не кожна із встановлених відмінних рис має бути беззаперечно упроваджена у вітчизняне законодавство. Втім, нами виділено три основних напрями, за якими такі зміни були б доречними:

- визначення мінімальної кількості типових адміністративних справ, необхідних для відкриття провадження у зразковій справі.

У даній роботі нами було запропоновано декілька варіантів того, яким чином можна було б удосконалити формулювання ч. 1 ст. 290 Кодексу адміністративного судочинства України 20 . Із урахуванням положень законодавства Литви, зміст цієї частини можна було б сформулювати наступним чином:

«[...] 1. Якщо у провадженні одного або декількох адміністративних судів перебуває двадцять або більше типових адміністративних справ, суд, який розглядає одну чи більше таких справ, може звернутися до Верховного Суду з поданням про розгляд однієї з них Верховним Судом як судом першої інстанції [...]».

- можливість оскарження ухвали суду про призупинення розгляду типової справи для іiі розгляду в порядку зразкової.

Частиною 1 ст. 291 Кодексу адміністративного судочинства України передбачено, що суд, який розглядає типову справу, має право зупинити провадження за клопотанням учасника справи або за власною ініціативою у випадку, якщо Верховним Судом відкрито провадження у відповідній зразковій справі. На нашу думку, надання учасникам справи та суду рівних прав ініціювати зупинення розгляду типової справи означає, що сторони також мають бути рівними і у правах щодо оскарження такої ініціативи. При цьому очевидно, що єдиною підставою для такого оскарження має бути невідповідність справи, яка розглядається, ознакам типової справи.

Для цього пропонуємо внести наступні зміни до ст. 291 Кодексу адміністративного судочинства України:

1) доповнити ії наступним положеннями:

«[...] 2. У разі зупинення провадження за ініціативою суду, який розглядає типову справу, ухвала суду про зупинення провадження може бути оскаржена на тій підставі, що справа, яка розглядається, не відповідає критеріям, передбаченим частиною 1 статті 290 цього Кодексу [...]»;

2) привести у відповідність до цього положення зміст усієї статті 291;

- розгляд типової справи, яка відповідає ознакам, викладеним у рішенні Верховного Суду за результатами розгляду зразкової справи, у порядку спрощеного позовного провадження.

Для цього:

1) пропонуємо доповнити ст. 291 Кодексу адміністративного судочинства України положеннями наступного змісту:

«[...] 4. Після набрання законної сили рішення Верховного Суду у зразковій справі типова справа розглядається за правилами спрощеного позовного провадження з урахуванням особливостей, визначених цією статтею. Суд постановляє ухвалу про розгляд типової справи за правилами спрощеного позовного провадження і протягом трьох робочих днів надсилає ії учасникам процесу. Ухвала про розгляд типової справи за правилами спрощеного позовного провадження не може бути оскаржена.

5. У передбаченому в частині 4 цієї статті спрощеному порядку можуть розглядатись лише ті типові справи, які були порушені після набрання законної сили рішення Верховного Суду у зразковій справі [...]»;

2) привести у відповідність до цих положень зміст усієї статті 291. Ст. 141

1 Конституція України: Закон України від 28.06.1996 № 254к/96-ВР. Відомості Верховної Ради України. 1996. № 30.

2 Стрілець Т.Г. Судова реформа: навіщо потрібні типові і зразкові справи : веб-ресурс «Судово-юридична газета». URL: https://sud.ua/uk/news/laws/109238-sudebnaya-reforma-zachem-nuzhny-tipichnye-i-obraztsovye-dela (дата звернення: 22.12.2019).

${ }^{3}$ Кодекс адміністративного судочинства України: Закон України від 06.07.2005 р. № 2747-IV. Вiдомості Верховної Ради України. 2005. № 35. 35-36. 37. С. 1358. Ст. 446.

${ }^{4}$ Europe Agreement establishing an Association between the European Communities and their Member States, of the one part, and the Republic of Lithuania, of the other part. Official Journal of the European Communities L. 1998. Vol. 41, № 51. P. 3-242.

5 Гаряча Ю.П. Адаптація законодавства країн Балтії до надбання спільноти (acquis communautaire): досвід для України. Науковий вісник Академії муніципального управління. Серія: Управління. 2012. Вип. 2. С. 193-200.

6 Угода про асоціацію між Україною, з однієї сторони, та Європейським Союзом, Свропейським співтовариством з атомної енергії і їхніми державами-членами, з іншої сторони: Міжнародний документ від 27.06.2014 р. Офіиійний вісник Украӥни. 2014. № 75. T. 1. С. 83. Ст. 2125. 
7 О производстве по административным делам: Закон Литовской Республики от 14.01.1999 г. № VIII-1029. URL: https://e-seimas.lrs.lt/portal/legalAct/lt/TAD/1ac36e42c13d11 e682539852a4b72dd4?jfwid=11dyheynok (дата звернення: 25.12.2019).

8 Великий тлумачний словник сучасної української мови / гол. ред. В.Т. Бусел, редактори-лексикографи: В.Т. Бусел, М.Д. Василега-Дерибас, О.В. Дмитрієв, Г.В. Латник, Г.В. Степенко. Київ : Ірпінь : Перун, 2005. 1728 с.

9 Там само.

10 Там само.

11 Кодекс адміністративного судочинства України: Закон України від 06.07.2005 р. № 2747-IV. Вiдомості Bepховної Ради Украӥни. 2005. № 35. 35-36. 37. С. 1358. Ст. 446.

12 Проект Закону про внесення змін до Господарського процесуального кодексу України, Цивільного процесуального кодексу України, Кодексу адміністративного судочинства України та інших законодавчих актів № 6232 від 23.03.2017 p. URL: http://w1.c1.rada.gov.ua/pls/zweb2/webproc4_1?pf3511=61415 (дата звернення: 23.12.2019).

13 О производстве по административным делам: Закон Литовской Республики от 14.01.1999 г. № VIII-1029. URL: https://e-seimas.lrs.lt/portal/legalAct/lt/TAD/1ac36e42c13d11e682539852a4b72dd4?jfwid=11 dyheynok (дата звернення: 25.12.2019).

14 Кодекс адміністративного судочинства України: Закон України від 06.07.2005 р. № 2747-IV. Вiдомості Верховної Ради Украӥни. 2005. № 35. 35-36. 37. С. 1358. Ст. 446.

15 Internet in Europe Stats. Internet User Statistics \& 2019 Population for the 53 European countries and regions: Internet World Stats. URL: https://internetworldstats.com/stats4.htm (дата звернення: 24.12.2019).

16 O производстве по административным делам: Закон Литовской Республики от 14.01.1999 г. № VIII-1029. URL: https://e-seimas.lrs.lt/portal/legalAct/lt/TAD/1ac36e42c13d11e682539852a4b72dd4?jfwid=11dyheynok (дата звернення: 25.12.2019).

17 Кодекс адміністративного судочинства України: Закон України від 06.07.2005 р. № 2747-IV. Вiдомості Верховної Ради України. 2005. № 35. 35-36. 37. С. 1358. Ст. 446.

18 О производстве по административным делам: Закон Литовской Республики от 14.01.1999 г. № VIII-1029. URL: https://e-seimas.lrs.lt/portal/legalAct/lt/TAD/1ac36e42c13d11e682539852a4b72dd4?jfwid=11dyheynok (дата звернення: 25.12.2019).

19 Там само.

${ }^{20}$ Кодекс адміністративного судочинства України: Закон України від 06.07.2005 р. № 2747-IV. Вiдомості Верховної Ради України. 2005. № 35. 35-36. 37. С. 1358. Ст. 446.

21 Проект Закону про внесення змін до Господарського процесуального кодексу України, Цивільного процесуального кодексу України, Кодексу адміністративного судочинства України та інших законодавчих актів № 6232 від 23.03 .2017 p. URL: http://w1.c1.rada.gov.ua/pls/zweb2/webproc4_1?pf3511=61415 (дата звернення: 23.12.2019).

\section{References:}

Konstytutsiia Ukrainy: Zakon Ukrainy № 254k/96-VR. (1996, chervnia 28). Vidomosti Verkhovnoi Rady Ukrainy, 30,141 [in Ukrainian].

Strilets, T.H. Sudova reforma: navishcho potribni typovi i zrazkovi spravy : veb-resurs «Sudovo-yurydychna hazeta». URL: https://sud.ua/uk/news/laws/109238-sudebnaya-reforma-zachem-nuzhny-tipichnye-i-obraztsovye-dela [in Ukrainian].

Kodeks administratyvnoho sudochynstva Ukrainy: Zakon Ukrainy № 2747-IV. (2005, lypnia 6). Vidomosti Verkhovnoi Rady Ukrainy, 35, 35-36, 37, 1358, 446 [in Ukrainian].

Europe Agreement establishing an Association between the European Communities and their Member States, of the one part, and the Republic of Lithuania, of the other part. (1998). Official Journal of the European Communities. L. 41, 51, 3-242 [in English].

Hariacha, Yu.P. (2012). Adaptatsiia zakonodavstva krain Baltii do nadbannia spilnoty (acquis communautaire): dosvid dlia Ukrainy. Naukovyi visnyk Akademii munitsypalnoho upravlinnia. Seriia: Upravlinnia, 2, 193-200 [in Ukrainian].

Uhoda pro asotsiatsiiu mizh Ukrainoiu, $\mathrm{z}$ odniiei storony, ta Yevropeiskym Soiuzom, Yevropeiskym spivtovarystvom $\mathrm{z}$ atomnoi enerhii i yikhnimy derzhavamy-chlenamy, z inshoi storony: Mizhnarodnyi dokument vid 27.06.2014 (2014, veresnia 26). Ofitsiinyi visnyk Ukrainy, 75, 1, 83, 2125 [in Ukrainian].

O proyzvodstve po admynystratyvnym delam: Zakon Lytovskoi Respublyky № VIII-1029. (1999, yanvaria 14). URL: https://e-seimas.lrs.lt/portal/legalAct/lt/TAD/1ac36e42c13d11e682539852a4b72dd4?jfwid=11dyheynok [in Russian].

Busel, V.T. (hol. red.). (2005). Velykyi tlumachnyi slovnyk suchasnoi ukrainskoi movy. K. : Irpin : Perun [in Ukrainian].

Proekt Zakonu pro vnesennia zmin do Hospodarskoho protsesualnoho kodeksu Ukrainy, Tsyvilnoho protsesualnoho kodeksu Ukrainy, Kodeksu administratyvnoho sudochynstva Ukrainy ta inshykh zakonodavchykh aktiv № 6232 (2017, bereznia 23). URL: http://w1.c1.rada.gov.ua/pls/zweb2/webproc4_1?pf3511=61415 [in Ukrainian].

Internet in Europe Stats. Internet User Statistics \& 2019 Population for the 53 European countries and regions: Internet World Stats. URL: https://internetworldstats.com/stats4.htm [in English].

\section{Резюме}

Миколаєць В.A. Зразкові та типові справи в адміністративному судочинстві Литви.

У статті проаналізовано специфіку зразкових та типових справ у адміністративному судочинстві Литви. Досліджено зміст кожного виду і виділено особливості адміністративно-правового регулювання даних питань у Литві. Виведено та сформульовано напрями запозичення позитивного досвіду у національне адміністративне законодавство.

Ключові слова: зразкові справи, типові справи, адміністративне судочинство, адміністративне законодавство, правосуддя.

\section{Резюме}

\section{Миколаеи В.А. Примерные и типовые дела в административном судопроизводстве Литвы.}

В статье проанализирована специфика примерных и типовых дел в административном судопроизводстве Литвы. Исследовано содержание каждого вида и выделены особенности административно-правового регулирования данных вопросов в Литве. Выведены и сформулированы направления заимствования положительного опыта в национальное административное законодательство.

Ключевые слова: примерные дела, типичные дела, административное судопроизводство, административное законодательство, правосудие. 


\section{Summary}

Victoria Mykolayets. Example and typical cases in the administrative judiciary of Lithuania.

In the article the specifics of model and typical cases in Lithuanian administrative proceedings are analyzed. The content of each type is investigated and features of administrative and legal regulation of these issues in Lithuania are highlighted.

The mechanism of model and typical cases in administrative justice was the institute of pilot decisions rendered by the European Court of Human Rights. Since the first pilot decision was made, the use of this tool was primarily aimed at reducing the burden on courts and judges. At its core, the pilot decisions of the European Court of Human Rights provide guidance to public authorities on the existence of a systemic problem with a large number of persons and recommendations to remedy the identified violations. By implementing the Institute of Pilot Solutions, two tasks were solved at once: first, an institute aimed at solving repeated problems was introduced; secondly, this mechanism facilitated the resolution of cases arising from the persistent systemic malfunctioning of the administrative and law enforcement bodies of the legal system of the state

The following features of the legal regulation of model and typical cases in the administrative judiciary of Lithuania are distinguished, which distinguish it from the Ukrainian model of legal regulation of these institutions:

1) model and typical cases were called "model" and "individual homogeneous", but their essence is identical;

2) model cases may be heard by local administrative courts;

3 ) at least 20 typical administrative cases must be kept in the proceedings of one or more administrative courts in order to open an exemplary case;

4) the decision to open a case in an exemplary case may be appealed by the participants of a typical case;

5) after the entry into force of a decision in an exemplary case, typical cases may be considered in a simplified manner.

The directions of borrowing positive experience in the national administrative legislation are outlined and formulated.

Key words: exemplary cases, typical cases, administrative justice, administrative legislation, justice.

DOI: 10.36695/2219-5521.4.2019.21

УдК 342:124.5

\section{O.P. РАДИШЕВСЬКА}

Олеся Ростиславівна Радишевська, кандидат юридичних наук, доцент Київського національного університету імені Тараса Шевченка, суддя Касаційного адміністративного суду в складі Верховного Суду*

ORCID: 0000-0002-3262-7487

\section{ВПЛИВ ПРОЦЕСУ ГЛОБАЛІЗАЦІЇ НА НАЦІОНАЛЬНЕ АДМІНІСТРАТИВНЕ ПРАВО: МІЖНАРОДНО-ПРАВОВИЙ ДИСКУРС}

Постановка проблеми. Еволюція завдань і функцій органів публічної влади під впливом внутрішніх і зовнішніх змін, що відбуваються у національній правовій системі кожної держави, а також на наднаціональному, міжнародному, глобальному рівнях, розвивається багатовекторно. Сучасна епоха цивілізаційного розвитку - це епоха диджиталізації, інформаційних технологій, а отже, і глобалізації, що охоплює динамічні міжнародні інтеграційні процеси у всіх напрямах життєдіяльності людини, зокрема у публічно-правовій сфері, що регулюється нормами адміністративного права крізь призму цінностей верховенства права.

На початку 2000-х рр. англійський учений П. Джонсон (P. Johnson) висловив думку, що великою справою минулого століття було наскрізне запровадження принципу верховенства права в суверенних державах, а справою наступного - його поширення на міжнародному і глобальному рівнях. При цьому робота над реалізацією першого проекту ще триває, а от другий - тільки починається1.

Глобалізація - це не тільки незворотний, а й необхідний процес, оскільки є певною культурною системою, яка дає змогу обмінюватися знаннями не тільки між поколіннями, але й між народами ${ }^{2}$ Проте досить критично процес глобалізації оцінюють учені В. Хаттон (W. Hutton) та А. Гідденс (A. Giddens). На їхню думку, він приводить не до уніфікації різних держав, не до об'єднання в єдиний ринок, а, навпаки, до різноспрямованості розвитку, до посилення відмінностей між державами, кожна з яких по-своєму реагує на виклики глобалізації, до глибоких трансформацій конфліктності та непередбачуваності світової системи господарювання

Ступінь наукової розробки проблеми. У наукових розвідках кінця ХХ ст. із політології, соціології, економіки і правознавства зарубіжні вчені та практики все більше звертають увагу на процес глобалізації та його вплив на еволюційний розвиток суспільства. Окреслені проблеми детально досліджували представники західноєвропейської і англосаксонської наук: 3. Бауман, З. Бжезинські, Д. Белл, Л. Браун, Е. Гор, Г. Гарт,

(C) О.Р. Радишевська, 2019

* Olesya Radyshevska, Ph.D. in Law, Associated Professor, Associated Professor of Taras Shevchenko National University of Kyiv, judge of Administrative Cassation Court of the Supreme Court 